\title{
HIDRÓLISE ENZIMÁTICA DE BIOMASSA
}

Thais Lucy Ogeda e Denise F. S. Petri*

Instituto de Química, Universidade de São Paulo, Av. Prof. Lineu Prestes, 748, 05508-900 São Paulo - SP, Brasil

Recebido em 9/6/09; aceito em 12/3/10; publicado na web em 20/7/10

\begin{abstract}
BIOMASS ENZYMATIC HYDROLYSIS. Production of ethanol from biomass fermentation has gained much attention recently. Biomass cellulosic material is first converted into glucose either by chemical or by enzymatic process, and then glucose is fermented to ethanol. Considering the current scenario, where many efforts are devoted for the search of green routes to obtaining ethanol from renewable sources, this review presents the relationship between structure and properties of cellulosic material, pre-treatments and hydrolysis of cellulosic material, and structure and function of cellulase enzyme complex.
\end{abstract}

Keywords: biomass; cellulose; hydrolysis.

\section{INTRODUÇÃO}

Atualmente, o sistema energético internacional é fortemente dependente de combustíveis fósseis (carvão, petróleo e gás), pois cerca de $80 \%$ do consumo mundial de energia se originam dessas fontes; o consumo apresenta um crescimento anual de cerca de $2 \%$ (média em 20 anos) e cresceu 3,1\% ao ano nos últimos 5 anos. ${ }^{1}$ Esta é uma situação que merece mudanças não só pela exaustão gradativa das reservas de combustíveis fósseis como também pelos efeitos negativos ao meio ambiente que resultam do seu uso, entre os quais o aquecimento global. A busca por combustíveis alternativos levou alguns países a optar por biocombustíveis devido principalmente a esse recente interesse na energia da biomassa, o que gerou combustíveis líquidos tais como o etanol produzido pela fermentação de açúcares (etanol de primeira geração) extraído, principalmente, da cana-deaçúcar, do milho, da beterraba, entre outras fontes. ${ }^{2}$ Outra via para a produção de etanol é pela hidrólise de biomassa celulósica, ${ }^{3,4}$ com geração de glicose, a qual pode ser fermentada produzindo etanol (etanol de segunda geração).

O Brasil está avançado quando se trata de substituir combustíveis fósseis, como a gasolina, por etanol renovável; o estado de São Paulo é um dos maiores produtores de cana-de-açúcar (68\% do total das plantações no país). ${ }^{5-9} \mathrm{O}$ Brasil produz cerca de 18 bilhões de litros de etanol combustível (dado da safra 2008/09 de maio/2009), ${ }^{10}$ o que representa $36 \%$ do total mundial. O Projeto Bioetanol ("Produção de Bioetanol através de Hidrólise Enzimática de Biomassa de Cana-deaçúcar"), iniciado em 2006 e financiado pela FINEP (Financiadora de Estudos e Projetos) através do Ministério de Ciência e Tecnologia (MCT) tem como meta viabilizar uma tecnologia para a conversão da celulose do bagaço e da palha da cana ao combustível etanol, já que apenas um terço da biomassa contida na planta cana é aproveitada para a produção de açúcar e etanol, ${ }^{11}$ minimizando a expansão dos canaviais. O Projeto Bioetanol é uma grande rede de pesquisa que agregou competências geradas ao longo da história brasileira, em especial pelo Proálcool, para desenvolver o processo de hidrólise enzimática de modo a torná-lo viável comercialmente. ${ }^{12}$

Projeto da FAPESP que também objetiva a produção de bioenergia no Brasil é o Programa BIOEN, o qual está voltado para aprimorar a produtividade do etanol brasileiro de $1^{\mathrm{a}}$ e $2^{\mathrm{a}}$ geração e avançar tanto em ciência básica quanto em desenvolvimento tecnológico relacionados à geração de energia a partir de biomassa. ${ }^{2,13} \mathrm{O}$ programa

*e-mail: dfsp@iq.usp.br já gerou uma série de trabalhos, indo desde o sequenciamento do genoma da cana-de-açúcar por um equipamento chamado Pirossequenciador $454^{14}$ até diversos workshops, como o Bioen on Sugarcane Improvement ${ }^{15}$ onde se discutiu tanto características intrínsecas da cana-de-açúcar - o seu genoma - como os parâmetros ambientais que aperfeiçoariam o crescimento e rendimento da planta. ${ }^{16}$ Em outro workshop, o BIOEN/PPP Etanol on Sugarcane Photosynthesis, ${ }^{17}$ que uniu o programa BIOEN a outro programa da FAPESP, o Programa de Pesquisa em Políticas Públicas (PPPP), responsável por financiar atividades de pesquisa que beneficiem a formulação e implementação de políticas públicas, cujos resultados tenham impacto no estado de São Paulo, ${ }^{18}$ discutiram-se as características da fotossíntese na canade-açúcar, os mecanismos de fixação de energia da planta e os meios para se alcançar uma melhor produtividade.

Basicamente, a biomassa celulósica é composta de cadeias de celulose (polissacarídeo formado por moléculas de glicose ligadas através de ligações $\beta$-1,4-glicosídicas) unidas entre si por ligações de hidrogênio. Essas longas fibras celulósicas são, por sua vez, recobertas por hemiceluloses (polissacarídeos ramificados formados principalmente por D-xilose com pequenas quantidades de L-arabinose, D-glicose, D-manose, D-galactose, ácido glucurônico e ácido manurônico) e ligninas (redes poliméricas tridimensionais formadas por unidades fenilpropano interligadas). ${ }^{19}$ As porções celulósicas e hemicelulósicas da biomassa, representando em torno de 40-50 e 20$30 \%$ do peso seco das plantas, respectivamente, são polissacarídeos que podem ser hidrolisados a açúcares e fermentados. As ligninas, quando degradadas a frações de massas molares menores, podem ser utilizadas na fabricação de espumas de poliuretanas, resinas fenólicas e epóxi, como fontes de fenol e etileno, ${ }^{20}$ e podem ser convertidas em fibras de carbono. ${ }^{21}$

Pode-se dizer de uma maneira simples que a obtenção de etanol a partir de biomassa envolve duas etapas. ${ }^{22}$ A primeira consiste na hidrólise dos polissacarídeos, gerando mono e dissacarídeos. A segunda etapa envolve a fermentação dos monos e dissacarídeos em etanol. A hidrólise de celulose gera glicose e celobiose (um dímero de glicose). Por outro lado, a hidrólise de ligninas e hemicelulose gera açúcares e subprodutos (principalmente, difenóis, derivados de fenilpropano, cetonas, furfural e ácido acético), que muitas vezes inibem a fermentação microbiana.

Os processos hidrolíticos não são triviais devido às complexas interações entre hemicelulose e celulose presentes nas paredes celulares dos vegetais e entre estes polissacarídeos e ligninas; à natureza cristalina da celulose e, à barreira física formada por ligninas ao 
redor das fibras celulósicas. Por esta razão, a biomassa sofre um prétratamento para separar a matriz de lignina, reduzir a cristalinidade da celulose e hidrolisar a hemicelulose, separando o hidrolisado da celulose, a qual sofre tratamento específico para a obtenção de glicose. Esta revisão descreve as características estruturais e propriedades de materiais celulósicos, a estrutura e função do complexo celulase, o pré-tratamento de biomassa e a hidrólise de material celulósico.

\section{ESTRUTURA E PROPRIEDADES DE MATERIAIS CELULÓSICOS}

Material celulósico ou lignocelulósico é um termo genérico para descrever os constituintes principais na maioria dos vegetais, ou seja, a celulose, a hemicelulose e a lignina, cuja composição depende não apenas do tipo de vegetal, mas também de condições de crescimento, ${ }^{23,24}$ da parte da planta escolhida,${ }^{25}$ da idade de colheita, etc. Entretanto, atualmente a pesquisa em genoma de plantas está sendo estimulada para otimizar a produtividade e composição de diferentes matérias-primas, com o intuito de facilitar a degradação e aumentar a produção de etanol. Por exemplo, uma seleção de diferentes clones híbridos de álamo tem resultado em um clone com percentual de celulose significantemente maior, além de um menor conteúdo de ligninas. ${ }^{26}$

A celulose é um polímero linear com ligações glicosídicas $\beta-1,4$ entre unidades D-glicopiranose. Tipicamente, cadeias de celulose em parede celular primária de plantas têm graus de polimerização (DP) na faixa de 5.000 a 7.500; o DP de celulose de madeira é em torno 10.000, e a de celulose de algodão 15.000. ${ }^{27}$ À temperatura ambiente, os anéis relativamente rígidos de glicose são todos encontrados em sua energia mais baixa, C4 mantido em conformação cadeira, não fazendo transições para outra conformação cadeira ou para várias possíveis formas barco-deformado. Com os anéis nesta conformação, todos os grupos hidroxilas ligados por ligações de hidrogênio e os substituintes hidroximetilas dos anéis de piranose são equatoriais, direcionados à periferia do anel, enquanto que os prótons hidrofóbicos alifáticos estão em posições axiais, apontando tanto para cima quanto para baixo, em relação ao plano médio dos anéis.

A estrutura cristalina da celulose foi primeiramente descrita por Mark e Meyer, em 1928. ${ }^{28}$ Desordem e polidispersidade no comprimento das cadeiras previnem a formação de cristais simples, e estudos de difração de raios- $X$ da estrutura cristalina da celulose têm sido limitados a experimentos de difração da fibra. ${ }^{19}$ A combinação de difração de raios-X com cálculos de modelo indica que cadeias de celulose cristalina estão em conformação de duplas hélices, achatadas e estendidas; pequenas variações nesta conformação ou no empacotamento das cadeias celulósicas dentro dos cristais levam a um bom número de polimorfos cristalinos, muitos dos quais podem ser interconvertidos por vários processos de tratamento. ${ }^{27,29}$ Sob condições normais, celulose é extremamente insolúvel em água, o que é necessário para sua própria função como sustentação estrutural nas paredes celulares vegetais. Sete formas cristalinas foram identificadas para celulose, e são designadas como I $\alpha$, I $\beta$, II, III I, III II IV e $\mathrm{IV}_{\mathrm{II}}$. As condições que permitem a interconversão entre elas estão representadas na Figura $1 .^{27}$

Cada uma destas formas cristalinas apresenta características físicas e químicas próprias, como solubilidade, densidade, ponto de fusão, forma do cristal, além de propriedades ópticas e elétricas. ${ }^{28,30}$ Na natureza, celulose I $\alpha$ e I $\beta$ são as mais abundantes e, logo, são chamadas de celulose nativa.

Celulose I $\alpha$ é o alomorfo majoritário produzido por fontes de bactérias e fungos e é um cristal triclínico $\mathrm{P}_{1}$ com um resíduo de celobiose por cela unitária. ${ }^{31}$ As cadeias de celulose são orientadas de modo paralelo como seria esperado para uma cela unitária com uma

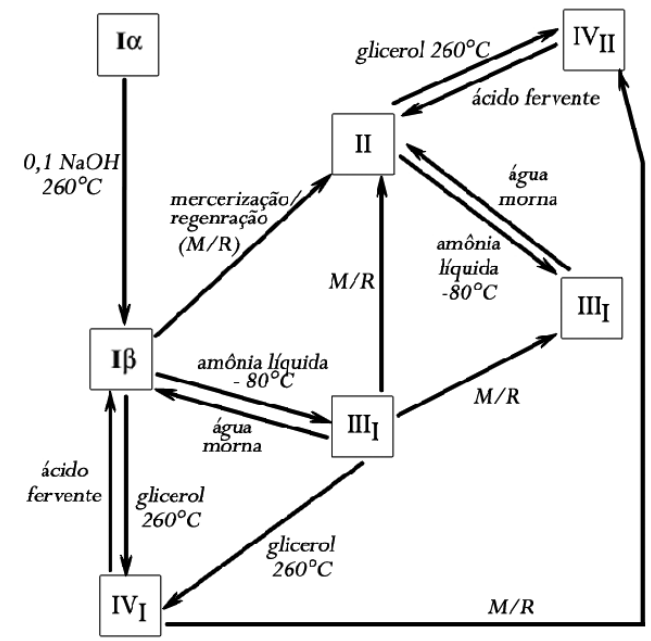

Figura 1. Representação das condições que permitem a interconversão entre as diferentes formas cristalinas da celulose. Adaptada da ref. 27

cadeia. Celulose I $\alpha$ é convertida à forma mais estável I $\beta$ através de um processo de recozimento a $270{ }^{\circ} \mathrm{C}$ em várias fontes. ${ }^{27}$ Celulose I $\beta$ é a forma cristalina majoritária em plantas superiores e é monoclínica na natureza, com duas metades de celobiose por cela unitária.

Celulose II é o polimorfo majoritário na indústria de processamento de celulose. Celulose II por ser formada a partir de regeneração ou mercerização da celulose I e é também o alomorfo termodinamicamente mais estável. Há outras características qualitativas importantes a respeito da conformação cristalina das cadeias individuais de celulose que devem ser notadas ${ }^{19}$ Como pode ser visto na Figura 2, na própria extensão da conformação cristalina, cada glicose está "torcida" em $180^{\circ}$ em relação à anterior e a seus anéis subsequentes, de forma tal que os grupos exocíclicos alcoólicos primários apontam alternadamente para a direita e para esquerda da direção da cadeia. A cadeia é estabilizada por ligações de hidrogênio fortes ao longo da direção das cadeias, do grupo exocíclico hidroxila alcoólico primário $\mathrm{O} 6$ ao grupo hidroxila alcoólico secundário $\mathrm{O} 2$ do resíduo subsequente, e do grupo hidroxila O3 para o anel de oxigênio O5 do próximo resíduo de açúcar. Estas ligações de hidrogênio ajudam a manter e reforçar a conformação linear e plana da cadeia para além da rigidez que poderia ser esperada para este tipo de ligação. É importante notar que, para a maioria dos modelos de celulose cristalina, não há ligações de hidrogênio entre as cadeias em diferentes camadas do cristal. Com todos os átomos de hidrogênio alifáticos em posições axiais e todos os grupos polares de hidroxilas em posições equatoriais, as partes superior e inferior das cadeias de celulose são, em essência, completamente hidrofóbicas, enquanto que as laterais das cadeias são hidrofílicas e capazes de fazer ligações de hidrogênio. Esta topologia é extremamente importante para o empacotamento das cadeias nos cristais. Em todos os esquemas propostos de empacotamento cristalino, as cadeias são empilhadas emparelhando as faces hidrofóbicas, as quais contribuem para a insolubilidade da celulose sob condições normais. ${ }^{19}$

A maioria dos polissacarídeos encontrados em paredes celulares vegetais pertence às celuloses, hemiceluloses ou classes de pectinas. Ainda que a celulose funcione como o componente rígido e sustentador de peso da parede celular, a rigidez da microfibra celulósica é reforçada dentro de uma matriz de hemiceluloses e pectinas.

Hemiceluloses são geralmente classificadas de acordo com o resíduo de açúcar principal no esqueleto, como, por exemplo, xilanas, mananas e glucanas. ${ }^{19}$ Dependendo da espécie da planta, estágio de desenvolvimento e tipo de tecidos, várias subclasses de hemiceluloses 


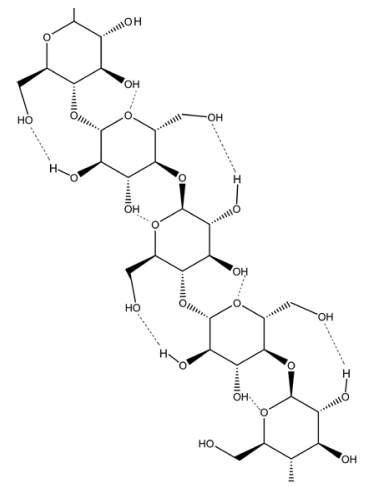

Figura 2. Celo-hexose mostrando a conformação planar e a "torcida" de $180^{\circ}$ dos resíduos de celobiose na celulose linear. Adaptada da ref. 19

podem ser encontradas, incluindo glucuronoxilanas, arabinoxilanas, mananas lineares, glicomananas, galactomananas, galactoglicomananas, $\beta$-glucanas e xiloglucanas. Arabinoxilanas, glucuronoxilanas, xiloglucanas e mananas lineares são pouco hidratados e, com exceção das mananas lineares (que servem como componente de armazenamento de sementes), eles estabilizam a parede celular através de interações de hidrogênio com a celulose e ligações covalentes com a lignina. Outras hemiceluloses como, por exemplo, galactoglicomananas, glicomananas, galactomananas e $\beta$-glucanas são usadas como energia extracelular e sistema de armazenagem dos produtos brutos, além de mecanismo de retenção de água em sementes. ${ }^{19}$ Acredita-se que as hemiceluloses estejam envolvidas na regulação da elongação e modificação da parede, e que as interações entre hemiceluloses e as microfibrilas de celulose sejam mais fortes do que as interações entre as hemiceluloses e ligninas. ${ }^{32} \mathrm{~A}$ composição química e características estruturais das hemiceluloses variam amplamente através de espécies, localizações sub-celulares e estágios de desenvolvimento. Geralmente as hemiceluloses estão quimicamente associadas ou reticuladas a outros polissacarídeos, proteínas ou ligninas.

Além da celulose, as $\beta$-glucanas e xiloglucanas possuem um importante papel na estrutura e função da parede celular porque estão envolvidas no suporte e reticulação da matriz celulósica através de ligações de hidrogênio com a celulose, com outras hemiceluloses e pectinas..$^{33,34}$ Estruturalmente elas são similares à celulose, pois seus esqueletos são formados por ligações $\beta$-glicosídicas. $\beta$-glucanas consistem de misturas de resíduos de $\beta$-(1-3) e $\beta$-(1-4) glicosídicas, enquanto que as xilanas são polissacarídeos que possuem um esqueleto de $\beta$-(1-4)-D-xilopiranose, com uma variedade de cadeias secundárias. ${ }^{35}$ A composição e ligação das cadeias secundárias determinam o tipo específico de variação da xilana. Removendo estas cadeias secundárias geralmente se eleva a taxa de degradação por enzimas endoxilanases. ${ }^{36}$ Os grupos laterais de xilanas podem ter um papel importante na ligação de ligninas com hemiceluloses. ${ }^{37,38}$ Grupos secundários, especialmente substituintes acetilas, afetam propriedades físico-químicas e biodegradabilidade das hemiceluloses solúveis ou presas à matriz. A acetilação aumenta a solubilidade do polissacarídeo em água, desfavorecendo o estado agregado. ${ }^{39,40}$ Por outro lado, a presença de ésteres ligados a resíduos de não-carboidratos faz com que as glucanases individuais não consigam liberar produtos de degradação uniforme, diminuindo a degradação enzimática dos polissacarídeos. ${ }^{40}$

O termo "mananas" indica um polímero linear de resíduos com ligações $\beta$-(1-4)-glicosídeas de manopiranosila. A estrutura e, logo, a degradação de mananas, são análogas à celulose. ${ }^{41}$ No entanto, mananas são encontradas em apenas algumas plantas particulares. Sua estrutura pode ser ramificada com diferentes combinações de resíduos de glicose e galactose, dando origem às muito mais comuns: glicomananas, galactomananas e galactoglicomananas.

\section{ESTRUTURA E FUNÇÃO DA CELULASE}

Celulase é um complexo enzimático, cujas enzimas atuam sinergicamente e estão subdivididas em três classes: endo-1,4- $\beta$-Dglucanases ou endoglucanases, que quebram as ligações glicosídicas das cadeias de celulose criando novos terminais; exo-1,4- $\beta$-Dglucanases ou celobio-hidrolases, responsáveis pela ação nos terminais levando à celobiose; e 1,4- $\beta$-D-glucosidades que hidrolisam a celobiose à glicose. ${ }^{22} \mathrm{~A}$ Figura 3 é uma representação simplificada da ação enzimática de cada classe de enzimas. As endo-1,4- $\beta$-glucanases ou 1,4- $\beta$-D-glucana-4-glucano-hidrolases (EC 3.2.1.4) atuam randomicamente nas regiões amorfas da celulose e de seus derivados, hidrolisando ligações glicosídicas $\beta-(1,4)$. Sua atividade catalítica pode ser medida através da diminuição da viscosidade do meio decorrente da diminuição de massa molar média de celulose ou derivados de celulose. ${ }^{42}$ As celobio-hidrolases (exo-1,4- $\beta$-D-glucanases, EC 3.2.1.91) atuam nos terminais redutores das cadeias de celulose, liberando D-celobiose, que pode ser detectada pelas técnicas de HPLC ou CG..$^{43}$ As " $\beta$-D-glucosidases" ou $\beta$-D-glucoside gluco-hidrolases (EC 3.2.1.21) catalisam a liberação de unidades monoméricas de D-glicose a partir da celobiose e celodextrinas solúveis. A atividade catalítica pode ser medida através da análise dos produtos por HPLC ou CG, ou mesmo por espectrofotometria. ${ }^{19}$

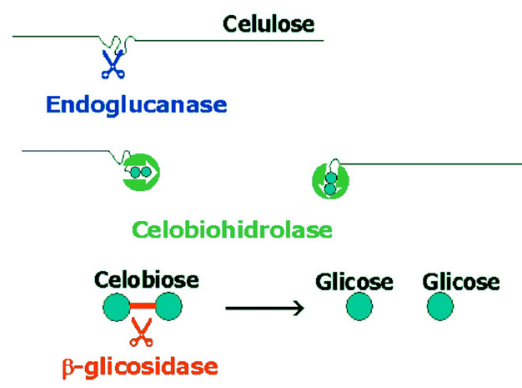

Figura 3. Representação esquemática da ação catalítica do complexo enzimático (celulase) sobre celulose com geração de glicose. Adaptada da ref. 48

O sistema da celulase de fungos foi largamente interpretado em termos de desenvolvimento substancial biológico molecular e bioquímico para o fungo Tricoderma reese - o primeiro fungo a ser utilizado na produção industrial de celulase, permanecendo ainda como a fonte mais utilizada. De várias maneiras, este sistema foi o sistema arquétipo desenvolvido de celulase. Muito da pesquisa subsequente neste campo focou em mutação/seleção de melhores descendências para comercialização da enzima, incluindo conversão em biomassa. Além de celulases de fungos, há celulases produzidas por bactérias aeróbicas e anaeróbicas. ${ }^{44}$ Recentemente foi publicada uma excelente revisão sobre os principais aspectos tecnológicos da produção e aplicação de celulases. ${ }^{45}$

T. reesei produz duas celobio-hidrolases, ao menos cinco endoglucanases e duas $\beta$-glucosidades. A Tabela 1 mostra classificação, substratos, características e teores relativos das celulases produzidas pelo T. reesei. ${ }^{22}$ A arquitetura molecular das endoglucanases e celobio-hidrolases tem um papel importante nas respectivas atividades catalíticas. Celobio-hidrolases $\mathrm{CBHI}$ apresentam terminais de pequenos glicopeptídeos, os quais se ligam à celulose e grandes núcleos proteicos que carregam o sítio ativo. ${ }^{46} \mathrm{De}$ fato, a maioria das endoglucanases e celobio-hidrolases consiste de um grande núcleo proteico e um pequeno domínio ligante de celulose unidos por sequências longas de aminoácidos (até $~ 60$ resíduos). O domínio ligante tem a função de aproximar o núcleo catalítico da superfície da celulose. Os 
sítios ativos das endoglucases estão expostos para fora da enzima, enquanto os sítios ativos das celobio-hidrolases estão dentro de um túnel. Por exemplo, no caso da CBHI do T. reesei, um túnel de $50 \AA ̊$ de comprimento e 10 sítios ligantes de celulose garantem a permanência da celulose dentro do túnel, enquanto ocorre a hidrólise. ${ }^{47}$

Tabela 1. Nomenclatura, substratos, massa molar média ponderal $\left(\mathrm{M}_{\mathrm{w}}\right)$, ponto isoelétrico (pI) e teores relativos das celulases produzidas pelo T. reesei. ${ }^{22} \mathrm{~A}$ família diz respeito à classificação de enzimas com sequências homólogas de aminoácidos similares, as quais geram estruturas tridimensionais e sítios ativos semelhantes e, portanto, mecanismos catalíticos semelhantes. Adaptada da ref. 49

\begin{tabular}{|c|c|c|c|c|c|}
\hline Enzima $^{a}$ & Substratos $^{\mathrm{b}}$ & Família & $\begin{array}{c}\mathrm{M}_{\mathrm{w}} \\
(\mathrm{kg} / \mathrm{mol})\end{array}$ & $\mathrm{pI}$ & $\begin{array}{c}\text { Teor relativo } \\
(\%)\end{array}$ \\
\hline $\begin{array}{l}\text { EGI } \\
\text { (Cel7B) }\end{array}$ & $\begin{array}{l}\text { CM, CA, CMC, } \\
\text { HEC, xilana }\end{array}$ & 7 & 48,2 & 4,5 & $6-10$ \\
\hline $\begin{array}{l}\text { EGII } \\
\text { (Cel5A) }\end{array}$ & $\begin{array}{c}\text { CM, CA, CMC, } \\
\text { HEC, galactomanana }\end{array}$ & 5 & 44,2 & 5,5 & $1-5$ \\
\hline $\begin{array}{l}\text { EGIII } \\
\text { (Cel12A) }\end{array}$ & $\begin{array}{c}\mathrm{CM}, \mathrm{CA}, \mathrm{CMC}, \\
\text { HEC }\end{array}$ & 12 & 25,2 & 7,5 & $<5$ \\
\hline $\begin{array}{l}\text { EGIV } \\
(\text { Cel161A) }\end{array}$ & $\begin{array}{c}\mathrm{CM}, \mathrm{CA}, \mathrm{CMC}, \\
\mathrm{HEC}\end{array}$ & 61 & 35,5 & d.d & d.d. \\
\hline $\begin{array}{l}\text { EGV } \\
(\mathrm{Cel} 45 \mathrm{~A})\end{array}$ & $\begin{array}{c}\mathrm{CM}, \mathrm{CA}, \mathrm{CMC}, \\
\mathrm{HEC}\end{array}$ & 45 & 24,4 & 2,9 & $<5$ \\
\hline $\begin{array}{l}\text { CBHI } \\
\text { (Cel7A) }\end{array}$ & $\mathrm{CC}, \mathrm{CM}, \mathrm{AC}$ & 7 & 54,1 & 3,9 & $60-75$ \\
\hline $\begin{array}{l}\text { CBHII } \\
\text { (Cel6A) }\end{array}$ & $\mathrm{CC}, \mathrm{CM}, \mathrm{AC}, \mathrm{CMC}$ & 6 & 49,7 & 5,9 & $10-20$ \\
\hline $\begin{array}{l}\text { BGI } \\
\text { (Cel3A) }\end{array}$ & $\mathrm{CB}, \mathrm{CT}$ & 3 & 78,4 & d.d. & $1-2$ \\
\hline $\begin{array}{l}\text { BGII } \\
(\text { Cel1A) }\end{array}$ & $\mathrm{CB}, \mathrm{CT}$ & 1 & 52,2 & d.d. & $1-2$ \\
\hline
\end{tabular}

d.d. - dados desconhecidos. ${ }^{\text {a Abreviações entre parênteses correspondem à }}$ classificação das famílias das glicosil hidrolases. ${ }^{\mathrm{b}}$ Substratos para os quais as celulases são ativas. CM-celulose microcristalina (Avicel), CA-celulose amorfa, CMC-carboximetil celulose, HEC-hidroxietil celulose, CC-celulose cristalina, CB-celobiose, CT-celotriose.

No mecanismo sinérgico exo-endo, as endoglucanases clivam randomicamente cadeias na superfície da celulose, fornecendo assim numerosos sítios adicionais para ataque das celobio-hidrolases. Logo, cada evento hidrolítico catalisado por uma endoglucanase resulta em novos sítios para as celobio-hidrolases. Entretanto, este mecanismo não é capaz de explicar porque o sinergismo entre endoglucanases e celobio-hidrolases é maior no início da hidrólise do que no fim do processo. ${ }^{50}$ No início, o número de terminais disponíveis para a celobio-hidrolase é abundante e o efeito das endoglucanases produzindo mais terminais é desprezível. Depois, o efeito sinérgico da produção de novos terminais celulósicos pelas endoglucanases deve ser maior. Por isso, uma extensão desta teoria foi proposta, a qual se baseia no modelo do obstáculo (ver refs. 51-53). Tal modelo sugere que a hidrólise progressiva das cadeias celulósicas pela celobio-hidrolases fica bloqueada devido a um obstáculo, que pode ser uma cadeia de celulose isolada cobrindo a superfície ativa da celulose. A função das endoglucanases é de remover o obstáculo e, assim, "reativar" a celobio-hidrolase; a ação da endoglucanase também resulta numa diminuição do comprimento da cadeia, o que irá reduzir a probabilidade da celobio-hidrolase ser presa novamente em um obstáculo. ${ }^{52}$

O papel de tantas endoglucanases é que parece não estar ainda muito claro. As duas endoglucanases EGI e EGIV possuem atividade para o mesmo substrato; a única diferença é que a atividade da EGIV é várias ordens de magnitude menor do que a EGI. ${ }^{54}$ Diferenças em $\mathrm{pH}$ e temperaturas ótimas podem ser uma das explicações para a produção de tantas endoglucanases. Já foi também especulado que o tamanho menor da EGV poderia permitir que ela penetrasse mais facilmente no material fibroso e, logo, ajudaria a abrir a estrutura do material. ${ }^{55}$

O processo de se ligar na celulose é a primeira etapa na degradação enzimática da celulose. Celulases que carregam tanto um domínio ligante de celulose livre como ligado a um peptídeo parecem altamente susceptíveis em se perder da celulose, pois pode ocorrer adsorção não específica e ligação não-produtiva de varias enzimas à celulose ${ }^{56} \mathrm{~A}$ ligação de enzimas $\mathrm{Cel} 7$, como as $T$. reesei $\mathrm{CBH} \mathrm{I}$, não segue o modelo de isoterma de adsorção de Langmuir, provavelmente porque os sítios de ligação para as proteínas na superfície da celulose não são energeticamente equivalentes. ${ }^{57}$ Lignocelulose apresenta-se como um substrato ainda mais complexo para a ação da celulase. Evidência clara de uma relação entre o conteúdo de lignina e a redução na hidrólise da celulose em substratos lignocelulósicos foi demonstrada na literatura. ${ }^{58}$

\section{PRÉ-TRATAMENTOS DE BIOMASSA}

A hidrólise da celulose à glicose em meio aquoso catalisado pelas enzimas celulase possui uma taxa de rendimento muito baixa, principalmente devida à estrutura altamente cristalina da celulose, a qual dificulta o acesso do substrato aos sítios ativos. ${ }^{59} \mathrm{~A}$ dificuldade aumenta também porque celulase adsorve fisicamente sobre ligninas. Além disso, a lignina restringe a hidrólise, pois esconde a superfície celulósica impedindo o intumescimento das fibras. Logo, torna-se necessária uma etapa de pré-tratamento, tanto a fim de quebrar a estrutura cristalina da lignocelulose quanto a fim de remover a lignina, expondo as moléculas de celulose e hemicelulose à ação enzimática.

Normalmente, hidrólises enzimáticas possuem um rendimento de açúcar menor que $20 \%$, enquanto que, se uma etapa de pré-tratamento for utilizada, o rendimento pode alcançar até $>90 \%{ }^{60}$ Atualmente, há uma grande quantidade de processos de pré-tratamento disponíveis, podendo ser físicos, químicos, biológicos ou de fracionamento por solvente. ${ }^{61}$ As operações físicas de pré-tratamento são baseadas na redução do tamanho da partícula através de moagem, aumentando a performance da enzima pelo aumento da área superficial e, em alguns casos, pela redução do grau de polimerização e cristalinidade da celulose. ${ }^{61,62}$

As principais tecnologias de pré-tratamento estão representadas junto aos pré-tratamentos químicos, incluindo pré-tratamentos ácidos, alcalinos ou oxidativos. Neste tipo de processo, a maior parte dos pré-tratamentos difere nos tipos de química e mecanismos responsáveis pelas modificações estruturais e químicas da parede celular, que resultam numa acessibilidade melhorada da enzima, além de rendimentos maiores. Em pré-tratamentos catalisados por ácidos a camada de hemiceluloses é hidrolisada, enquanto que nos pré-tratamentos catalisados por bases, parte da lignina é removida e a hemicelulose tem que ser hidrolisada pelo uso de hemicelulases. Uma das tecnologias de pré-tratamentos mais amplamente implementada é a explosão a vapor, que tem sido aplicada com sucesso a diversos tipos de biomassa celulósica (madeiras macias e duras, além de resíduos agrícolas). ${ }^{63}$ Esse processo pode ocorrer com ou sem a presença de catalisadores químicos (ácido sulfúrico, dióxido de enxofre, ${ }^{64}$ hidróxido de sódio e amônia).$^{65}$ Opera a altas temperaturas $\left(160-290{ }^{\circ} \mathrm{C}\right) \mathrm{e}$ pressão, durante um certo período de tempo (de alguns segundos até vários minutos), antes que a pressão seja liberada explosivamente.

Os pré-tratamentos biológicos normalmente utilizam fungos e algumas bactérias (actinomicetes). Durante o processo, estes microorganismos secretam enzimas extracelulares como lignina peroxidases e lacases que ajudam a remover uma quantidade considerável de lignina da biomassa. A empresa de pesquisa em biocombustíveis Mascoma Corporation ${ }^{66}$ desenvolveu o bioprocessamento consolidado, no qual as celulases são produzidas pelo mesmo micro-organismo que fermenta os açúcares em etanol em uma única etapa. 
A categoria de pré-tratamento de fracionamento por solvente aplica o conceito da solubilização diferencial e do fracionamento dos vários componentes da parede celular vegetal, incluindo a celulose, pelo rompimento das ligações de hidrogênio entre as microfibras. ${ }^{67}$ Há muitos métodos disponíveis hoje em dia; os mais atraentes são os processos organosolv, fracionamento por ácido fosfórico ${ }^{68} \mathrm{e}$ os baseados em líquidos iônicos. ${ }^{61}$

Uma comparação direta dos rendimentos resultantes de açúcar pelos métodos de pré-tratamento conhecidos é difícil devido às variações de como os rendimentos são relatados e quais açúcares estão incluídos. A Tabela 2 sumariza as vantagens e desvantagens de cada um deles.

O uso de líquidos iônicos como meio para dissolução e hidrólise de biomassa caracteriza-se como um potencial pré-tratamento. ${ }^{69} \mathrm{Lí}-$ quidos iônicos são substâncias compostas de íons e líquidas $\left(<100^{\circ} \mathrm{C}\right)$ à temperatura ambiente. $\mathrm{O}$ interesse nestes compostos, comumente anunciados como o "meio verde" e a "alta tecnologia do futuro", está aumentando devido à baixíssima pressão de vapor, estabilidade térmica, além das várias propriedades ajustáveis, como polaridade, hidrofobicidade e miscibilidade com solventes (pela modificação apropriada do cátion e do ânion). Líquidos iônicos demonstram um grande potencial de revolucionar a tecnologia das reações. Sua síntese, propriedades físico-químicas e campos de aplicação têm sido revisados, com seu número de aplicações como meio de reação para catálise e sistemas orgânicos estando em constante crescimento. Muitos tipos de líquidos iônicos com alto grau de pureza estão agora comercialmente disponíveis.

Especialmente na química de carboidratos e polissacarídeos os líquidos iônicos vêm ganhando um espaço especial. ${ }^{70-72}$ Por exemplo, alguns líquidos iônicos hidrofílicos como o cloreto de 1-butil-3metilimidazólio ([BMIM]Cl) e cloreto de 1-alil-3-(1-metil)imidazólio são excelentes solventes para celulose. A Tabela 3 nos dá exemplos de solubilidade, utilizando celulose de alta massa molecular (DP $\approx$ 1000), sem pré-tratamento. A maior solubilidade de celulose em [BMIM]Cl, observada a partir de análise comparativa dos dados da Tabela 3 , pode ser devida à maior penetração dos íons na extensa rede de ligações de hidrogênio entre as cadeias de celulose, permitindo uma dissolução mais rápida. Já a presença de água no líquido iônico diminui significantemente a solubilidade da celulose. ${ }^{70}$ Após a dissolução em líquido iônico a celulose pode ser regenerada pela adição de água, etanol ou acetona à solução. A celulose regenerada possui graus de polimerização e polidispersidade semelhantes aos iniciais, indicando que não há degradação das cadeias de celulose pelo líquido iônico. Entretanto, a morfologia inicial de microfibras se transforma em uma macroestrutura homogênea, revelando perda de cristalinidade após a regeneração. ${ }^{73}$ Resultados semelhantes foram obtidos para

Tabela 2. Sumário das vantagens e desvantagens dos diferentes métodos de pré-tratamento e hidrólise de material celulósico. Adaptada da ref. 22

\begin{tabular}{|c|c|}
\hline Método & Vantagens \\
\hline \multicolumn{2}{|l|}{ Métodos diretos } \\
\hline Ácido concentrado & $\begin{array}{l}\text { - Alto rendimento de glicose } \\
\text { - Pouca formação de inibidores } \\
\text { - Realizado à temperatura ambiente }\end{array}$ \\
\hline Ácido diluído & $\begin{array}{l}\text { - Menos problemas com corrosão quando comparado a } \\
\text { ácido concentrado } \\
\text { - Método de duas etapas: bom rendimento de glicose } \\
\text { e de açúcares de hemicelulose }\end{array}$ \\
\hline \multicolumn{2}{|l|}{ Pré-tratamentos Físicos } \\
\hline $\begin{array}{l}\text { Moagem ou Vibração - seca } \\
\text { ou úmida }\end{array}$ & $\begin{array}{l}\text { - Diminui o tamanho da partícula, aumentando } \\
\text { a área superficial } \\
\text { - Em alguns casos, reduz o DP e a cristalinidade }\end{array}$ \\
\hline \multicolumn{2}{|c|}{ Pré-tratamentos de Fracionamento por Solvente } \\
\hline Processo Organosolv & $\begin{array}{l}\text { - Solubiliza ligninas e hemiceluloses (dependendo } \\
\text { do solvente utilizado) } \\
\text { - Aumento da digestibilidade da biomassa celulósica }\end{array}$ \\
\hline $\begin{array}{l}\text { Fracionamento por Ácido } \\
\text { Fosfórico }\end{array}$ & $\begin{array}{l}\text { - Resulta em fibras de celulose amorfas } \\
\text { - Opera a baixa temperatura e pressão } \\
\text { - Altos rendimentos de glicose e xilose }\end{array}$ \\
\hline Líquidos Iônicos & $\begin{array}{l}\text { - Reuso do líquido iônico após o processo } \\
\text { - Substrato final com digestibilidade }>90 \%\end{array}$ \\
\hline
\end{tabular}

Pré-tratamentos Químicos

Explosão à Vapor (com/ sem adição de ácido como catalisador)

- Ótimo para madeira macia (na presença de um catalisador ácido)

- Altos rendimentos de glicose e açúcares de hemicelulose

Expansão da fibra com amônia - Pouco gasto de energia: pré-tratamento realizado (AFEX) a temperaturas de $60-140^{\circ} \mathrm{C}$

- Baixa formação de inibidores

Oxidação Úmida Alcalina

- Formação mínima de inibidores

- Remoção eficiente de lignina

- Processo exotérmico: pouca energia necessária no processo

Desvantagens

- Alto custo do ácido ou na recuperação do ácido utilizado

- Equipamento caro devido a problemas de corrosão

- Formação de produtos de degradação

- Necessidade de reatores mais sofisticados para

obtenção de altos rendimentos

- Concentração baixa de açúcar no fluxo de saída

- Não é suficiente para aumentar a taxa de conversão de açúcar

- Não retira lignina

- Alto custo dos solventes orgânicos, bem como na sua recuperação

- Alto custo na recuperação de subprodutos

- Taxa de líquido-sólido deve ser fixada com cuidado

- Alto custo na recuperação e purificação do ácido fosfórico, acetona e ácido acético

- O líquido iônico deve ser completamente retirado antes da hidrólise (interfere na atividade hidrolítica das enzimas)

- Alto custo dos líquidos iônicos

- Formação de produtos de degradação

- Uma etapa adicional é necessária para a remoção da lignina

- Alto custo: grande quantidade de amônia necessária, recuperação da amônia

- A fração da hemicelulose precisa ser hidrolisada por enzimas

- Remoção desprezível de ligninas

- Custo de oxigênio e catalisador alcalino $\left(\mathrm{Na}_{2} \mathrm{CO}_{3}\right)$

Pré-tratamentos Biológicos

Uso de Fungos (white rot basidiomycetes) ou bactérias (Actinomicetes)

- Remove quantidade considerável de lignina

- Pré-tratamento brando (ótimo para materiais com alto conteúdo de carboidratos)
- Maior tempo de residência

- Bactérias/fungos consomem um pouco do carboidrato disponível menor rendimento de açúcar 
celulose microcristalina regenerada a partir de solução em cloreto de 1-alil-3-(1-butil)imidazólio ${ }^{73}$ ou acetato de 1-etil-3-metilimidazólio ([EMIM]Ac).$^{74}$ Portanto, o uso de líquidos iônicos como solvente é um excelente pré-tratamento de celulose, o qual leva à redução de cristalinidade da celulose e consequente aumento dos rendimentos nos processos hidrolíticos e da produção de açúcares fermentáveis.

Tabela 3. Solubilidade de celulose de alta massa molar (DP 1000) em líquidos iônicos. DMIM, AMIM, EMIM, BMIM, HMIM e OMIM representam os cátions 1,3-dimetilimidazólio, 1-alil-3-metilimidazólio, 1-etil-3-metilimidazólio, 1-butil-3-metilimidazólio, 1-hexil-3-metilimidazólio e 1-octil-3-metilimidazólio, respectivamente. Adaptada das refs. 70 e 72

\begin{tabular}{lcc}
\hline Líquido iônico & Método & $\begin{array}{c}\text { Solubilidade } \\
(\mathrm{m} / \mathrm{m} \%)\end{array}$ \\
\hline$[\mathrm{DMIM}]\left[\left(\mathrm{CH}_{3}\right)_{2} \mathrm{PO}_{4}\right]$ & Aquecimento $\left(30^{\circ} \mathrm{C}\right)$ & 2 \\
{$[\mathrm{AMIM}] \mathrm{Cl}$} & Aquecimento $\left(80^{\circ} \mathrm{C}\right)$ & $2,9-5$ \\
{$[\mathrm{EMIM}] \mathrm{Cl}$} & Aquecimento $\left(97^{\circ} \mathrm{C}\right)$ & 4 \\
{$[\mathrm{EMIM}] \mathrm{Ac}$} & Aquecimento $\left(80^{\circ} \mathrm{C}\right)+900 \mathrm{rpm}$ & $3-4$ \\
& Aquecimento $\left(110^{\circ} \mathrm{C}\right)$ & $\sim 10$ \\
{$[\mathrm{BMIM}] \mathrm{Cl}$} & Aquecimento $\left(70{ }^{\circ} \mathrm{C}\right)$ & 3 \\
& Aquecimento $\left(80{ }^{\circ} \mathrm{C}\right)+$ ultrassom & 5 \\
& Aquecimento $\left(100^{\circ} \mathrm{C}\right)$ & 10 \\
{$[\mathrm{BMIM}] \mathrm{Br}$} & Aquecimento por microondas, & 25, solução \\
{$[\mathrm{BMIM}] \mathrm{SCN}$} & pulsos de $3-5-\mathrm{s}$ & $5-7$ \\
{$[\mathrm{BMIM}]\left[\mathrm{BF}{ }_{4}\right]$} & Micro-ondas & $5-7$ \\
{$[\mathrm{BMIM}]\left[\mathrm{PF}{ }_{6}\right]$} & Micro-ondas & Insolúvel \\
{$[\mathrm{HMIM}] \mathrm{Cl}$} & Micro-ondas & Insolúvel \\
{$[\mathrm{OMIM}] \mathrm{Cl}$} & Micro-ondas & 5 \\
\hline
\end{tabular}

Estudos de hidrólise enzimática de celulose em líquidos iônicos mostraram que há uma perda da atividade enzimática da celulase em [BMIM] $\mathrm{Cl}^{75} \mathrm{~A}$ inibição da celulase acontece pela alta força iônica da solução, a qual provoca desnaturação e inativação da enzima. Mesmo efeito é observado para celulase em acetato de [EMIM]Ac. ${ }^{74}$ A Figura 4 mostra espectros de dicroísmo circular de celulase de $T$. reseei em água, em acetato de EMIM puro e na mistura de acetato de EMIM e água (5\%/95\% v/v). Nota-se que a banda em $216 \mathrm{~nm}$, característica de $\alpha$ hélices da estrutura nativa da celulase, desaparece na presença do líquido iônico, mesmo em misturas contendo somente $5 \%$ de acetato de EMIM, indicando desnaturação da enzima. Por outro lado, estudo recente mostrou que em misturas de dietilfosfato de 1-etil3-metilimidazólio e água na razão volumétrica de 1:4 proporcionou condições favoráveis para celulase, que converteu $70 \%$ da celulose a glicose e celobiose. ${ }^{76}$

A hidrólise ácida é aprimorada em líquidos iônicos. ${ }^{77}$ Além de $\mathrm{H}_{2} \mathrm{SO}_{4}$, outros ácidos minerais incluindo $\mathrm{HCl}, \mathrm{HNO}_{3}$ e $\mathrm{H}_{3} \mathrm{PO}_{4}$ foram testados, utilizando [BMIM] Cl como solvente. Quando a celulose é completamente dissolvida no líquido iônico, se forma uma solução homogênea, de modo que as ligações $\beta$-glicosídicas se tornam mais acessíveis aos íons $\mathrm{H}^{+}$, ao contrário de outros meios, onde somente a superfície da celulose fica acessível, consequentemente, as taxas de conversão são mais altas.

\section{HIDRÓLISE DE MATERIAL CELULÓSICO}

Com o passar dos anos, vários métodos foram propostos para hidrólise de material celulósico. Comum a todos estes métodos é que o material deve ser antes mecanicamente quebrado ou moído, a fim de aumentar a área superficial. ${ }^{78}$ Duas rotas são frequentemente

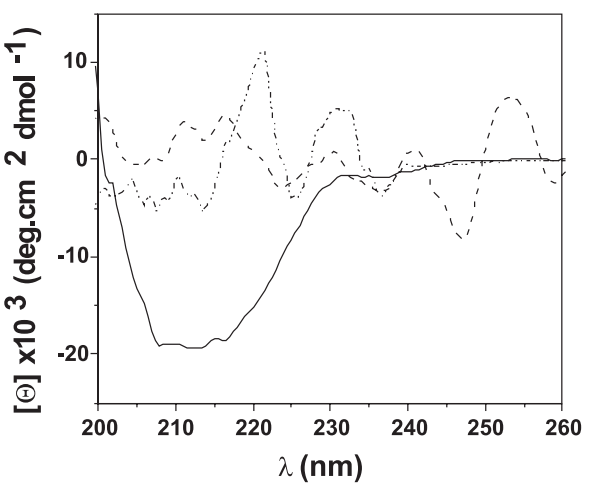

Figura 4. Espectros de dicroísmo circular obtidos para celulase em água (linha contínua), na mistura de água e [EMIM]Ac (95/5\% v/v) (linha pontilhada) e em [EMIM]Ac puro (linha tracejada). Ref. 74

empregadas para a hidrólise. A primeira é o uso de hidrólise ácida e a segunda é a hidrólise enzimática do material pré-tratado. Em ambos os casos, há vários modos de operação; a escolha deve ser baseada em várias considerações como, por exemplo, qual o produto bruto que será usado, o organismo usado para a fermentação dos açúcares liberados, além da economia.

Hemicelulose e celulose podem ser hidrolisadas a açúcares e fermentados microbianamente a vários produtos como o etanol, ou serem convertidas quimicamente em outros produtos. ${ }^{79-87}$ As cadeias de hemicelulose são formadas por monômeros de arabinose ou xilose, a hidrólise da hemicelulose resulta em moléculas de arabinose ou xilose (pentoses). A hemicelulose também pode sofrer ataques a posições intermediárias ao longo de seu esqueleto, liberando oligômeros feitos de muitas moléculas de açúcares; estas podem ser sucessivamente quebradas em oligômeros ainda menores, antes que uma molécula de um simples açúcar possa ser formada. ${ }^{88}$ Tal quebra pode ser catalisada por enzimas conhecidas como hemicelulases ou por ácidos diluídos, com os últimos utilizando temperaturas de 100$200{ }^{\circ} \mathrm{C}$, onde se formam produtos de degradação, se o objetivo for bons rendimentos de açúcares de hemicelulose em solução. Apesar de tudo, a degradação dos açúcares liberados pode ser modesta o suficiente para recuperar cerca de $80-90 \%$ do máximo possível de açúcares. ${ }^{89}$ Por outro lado, operações sem a adição de ácido limitam a recuperação dos açúcares de hemicelulose para $65 \%$ ou menos, com a maioria na forma de oligômeros. ${ }^{90}$

Em água pura a hidrólise da celulose ocorre espontaneamente, porém, de forma extremamente lenta. ${ }^{91}$ Ácidos ou celulase catalisam a reação de água com moléculas de glucanas liberando mono, di e/ ou trissacarídeos.

A hidrólise ácida inicia com a protonação do oxigênio glicosídico (Figura 5a) com posterior quebra da ligação $\mathrm{C}_{1}-\mathrm{O} .^{91,92} \mathrm{O}$ carbocátion gerado na etapa b é estabilizado pela deslocalização do par de elétrons existente sobre o oxigênio do anel glicosídico, adjacente $\mathrm{a}_{1}$. $\mathrm{O}$ ataque nucleofílico da água sobre $\mathrm{C}_{1}$ (Figura $5 \mathrm{c}$ ) com regeneração do ácido (Figura 5d e 5e) encerra a etapa de despolimerização (se esta ocorrer no interior da cadeia da celulose, gerando novos terminais) ou de produção de glicose (quando ocorre hidrólise diretamente nos terminais).

A hidrólise com ácido concentrado é feita a baixas temperaturas (cerca de $30^{\circ} \mathrm{C}$ ) e resulta em rendimentos altos tanto de hexoses quanto de pentoses (85-90\% da teoria), ${ }^{93,94}$ causando apenas uma limitada quantidade de produtos de degradação de açúcares. ${ }^{95,96} \mathrm{O}$ uso de grandes quantidades de ácido necessita de uma recuperação eficiente do ácido. Esta é uma das maiores desvantagens desde método, já que a recuperação é um processo que demanda energia, além de ser uma etapa cara. ${ }^{94}$ Além disso, a natureza corrosiva do ácido requer o uso de ligas caras na construção de canos e trocadores de calor. 


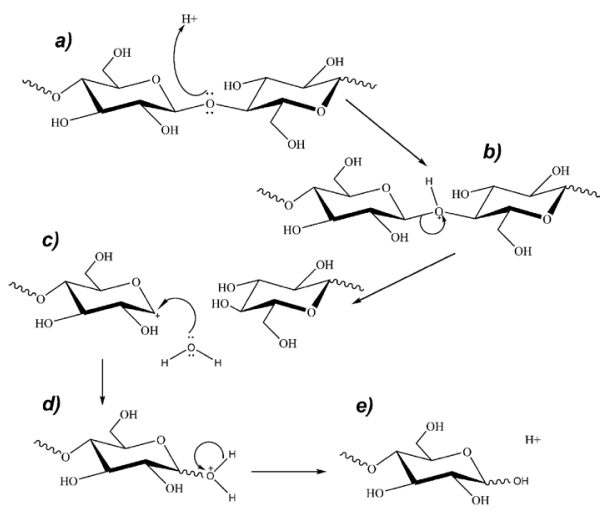

Figura 5. Mecanismo de hidrólise da celulose catalisada por ácido. Adaptada da ref. 92

Ácido diluído também foi usado com sucesso para a hidrólise de material lignocelulósico em escala comercial desde o começo de 1930 (o processo Scholler ou Madison de percolação). ${ }^{95,97} \mathrm{O}$ ácido mais comumente utilizado é o $\mathrm{H}_{2} \mathrm{SO}_{4}$, devido ao seu menor preço e poucos problemas com corrosão quando comparado ao, por exemplo, $\mathrm{HCl}$. O uso de concentrações baixas de ácido $(<1 \%)$ demanda o uso de altas temperaturas $\left(180-230^{\circ} \mathrm{C}\right)$ para alcançar taxas de reações aceitáveis na hidrólise da celulose, além de obter altos rendimentos de glicose. ${ }^{95,98}$ Entretanto, em temperaturas elevadas, as pentoses da hemicelulose, e numa extensão menor as hexoses, são rapidamente degradadas. A formação de produtos de degradação pode inibir a fermentação; portanto, a hidrólise com ácido diluído é dividida em duas etapas. Na primeira, a hemicelulose, principalmente, é hidrolisada em condições menos severas com temperaturas em torno de $170-190{ }^{\circ} \mathrm{C}$, e concentrações de ácido de 0,5-1,2\% (m/m). ${ }^{99-102}$ Depois, os sólidos restantes são removidos e tratados na segunda etapa sob temperaturas na faixa de 200 a $230{ }^{\circ} \mathrm{C}$ e em concentrações maiores de ácido (até $2,5 \% \mathrm{~m} / \mathrm{m}$ )..$^{93,99,102}$ Isto resulta em um rendimento total de $50-60 \%$ para a glicose e quase a $90 \%$ para açúcares da hemicelulose dos rendimentos teóricos. ${ }^{94,102,103}$

Cadeias longas de celulose, quando aquecidas a altas temperaturas com ácido sulfúrico diluído, quebram grupos mais curtos de moléculas que liberam glicose e que, por sua vez, pode ser degradada a hidroximetil furfural. ${ }^{104}$ Geralmente, a maior parte da celulose é cristalina, e condições extremas (altas temperaturas, altas concentrações de ácido) são necessárias para liberar glicose destas cadeias fortemente associadas. Além disso, o rendimento aumenta com a temperatura, chegando até $70 \%$ a $260{ }^{\circ} \mathrm{C} .{ }^{104}$ Entretanto, a geração de alcatrão e outros produtos secundários difíceis de lidar ${ }^{105}$ e o difícil controle do tempo de reação para rendimento máximo de glicose são grandes desafios comerciais.

A hidrólise ácida da hemicelulose é similar à da celulose.${ }^{19}$ Entretanto, como a hemicelulose é amorfa, condições menos severas são necessárias para liberar os açúcares da hemicelulose. Vapor é injetado diretamente à biomassa para aquecê-la rapidamente, e o ácido acético contido nas cadeias de hemiceluloses pode gerar íons de hidrogênio para promover a hidrólise. Apesar disso, neste caso, os rendimentos de açúcares de hemicelulose são limitados a cerca de $65 \%$ do máximo possível. ${ }^{90}$ Por outro lado, adicionar ácido sulfúrico ou outros ácidos resulta em rendimentos mais altos e celulose mais digestiva a um preço menor. ${ }^{89,106}$ Por exemplo, rendimentos de $80-90 \%$ dos açúcares podem ser recuperados da fração da hemicelulose com temperaturas em torno de $160{ }^{\circ} \mathrm{C}$, tempos de reação de cerca de 10 min e níveis ácidos de $0,7 \% .^{89}$ Além disso, aproximadamente $90 \%$ da celulose sólida restante pode ser digerida enzimaticamente para produzir glicose. Estes altos rendimentos são vitais para baixos custos ${ }^{79,81,83,85}$ e têm motivado o uso de ácido sulfúrico diluído na hidrólise ácida para aplicações a curto prazo. ${ }^{83,85}$ Apesar de considerada inovadora, a hidrólise com ácido sulfúrico diluído é cara; seu ambiente corrosivo demanda o uso de materiais de construção caros. ${ }^{79,81,83,85}$ Além disso, produtos de degradação, como fragmentos de furfural e lignina, e compostos de biomassa solubilizada, como acido acético, devem ser removidos por serem inibitórios para fermentação microbiana. ${ }^{107,108}$

Industrialmente a conversão enzimática da celulose a etanol envolve operações de pré-tratamento para retirar ligninas e expor celulose e hemicelulose ao ataque da celulase. ${ }^{96,100,109,110}$ Após o pré-tratamento começam as operações de hidrólise e fermentação. Quando a hidrólise ocorre sequencialmente à fermentação a operação é designada de SHF - Separate Hydrolysis Fermentation. O problema nesta operação é que a glicose e celobiose permanecem no mesmo meio que a celulose e celulase e estes mono e dissacarídeos inibem a ação da celulase. Embora os rendimentos possam ser melhorados adicionando grandes quantidades de celulase, esta estratégia aumenta o custo do processo. Para contornar este problema adiciona-se o micro-organismo fermentativo ao mesmo vasilhame onde estão sendo produzidos os açúcares. Desta forma, glicose e celobiose são rapidamente fermentadas a etanol, reduzindo o acúmulo destes inibidores de celulase ${ }^{111}$ e de custos de equipamentos e de produção de etanol. ${ }^{81} \mathrm{~A}$ baixa concentração de glicose livre e a presença de etanol também fazem com que seja mais difícil para micro-organismos invasivos tomarem o comando das reações de fermentação, formando produtos indesejáveis. Esta estratégia é conhecida como processo de sacarificação simultânea e fermentação, SSF (Simultaneous Saccharification and Fermentation). Embora a temperatura do processo SSF tenha que ser reduzida abaixo do ótimo, o desempenho é melhor em termos de taxas, rendimentos e concentrações de etanol do que na hidrólise separada a altas temperaturas (que são ótimas para a hidrólise da celulose).$^{81}$

Industrialmente o uso de celulases ainda é proibitivo devido ao seu alto custo. De modo geral, a catálise enzimática deve combinar eficiência e baixo custo. Uma maneira de fazer o processo enzimático economicamente viável é imobilizar enzimas sobre substratos sólidos, de tal forma que as propriedades catalíticas sejam mantidas, além de serem reutilizadas muitas vezes. O grande desafio é que ao imobilizar a enzima, esta mantenha sua estrutura nativa. A força motriz que dirige a adsorção de muitas proteínas e enzimas é o ganho entrópico devido às mudanças conformacionais, mudanças estas que podem desnaturar as macromoléculas biológicas. ${ }^{12}$ Em muitos casos, a imobilização sobre substratos hidrofílicos favorece a manutenção da estrutura nativa das biomoléculas, porque a camada de hidratação é mantida. Este comportamento já foi observado para hexoquinase, ${ }^{113}$ enolase, ${ }^{114}$ fosfatase, ${ }^{115}$ creatina fosfoquinase,${ }^{116}$ peroxidases. ${ }^{117}$

Celulase tem sido imobilizada sobre diferentes substratos. Celulase ligada covalentemente à superfície externa de lipossomos modificados com grupos aldeídos apresentou alta atividade enzimática. ${ }^{118}$ Celulase imobilizada sobre microesferas e esponjas de quitosana puderam ser utilizadas 10 vezes consecutivas, e apenas depois de 8 (para microsesferas) e 9 (para esponjas) vezes é que foi observada perda de $50 \%$ da atividade relativa. ${ }^{119}$ Celulase adsorvida sobre nanofibras de poli(álcool vinílico) apresentou atividade $65 \%$ superior à da enzima livre, sendo reutilizadas 6 vezes com perda de $64 \%$ da atividade inicial. ${ }^{120}$ Celulase aderida sobre suportes de nylon ou quitina ${ }^{121}$ ou mesmo ligada covalentemente a espumas de poliuretano apresentou boa eficiência. ${ }^{122} \mathrm{~A}$ coimobilização de celulase e glicose isomerase em partículas de poliestireno modificado com p-trimetilamina permitiu a conversão de celulose em glicose e frutose numa taxa molar de 60:40, retendo $50 \%$ da atividade inicial após 5 ciclos de uso. ${ }^{123}$ Celulase adsorvida sobre lâminas de silício com camada nativa de $\mathrm{SiO}_{2}$ apresentou atividade $20 \%$ menor que a de celulase livre e pôde ser reutilizada 6 vezes sem perda de atividade catalítica. ${ }^{48}$ 
Em geral, tanto celulases livres como imobilizadas apresentam maior atividade na faixa de temperatura de 60 a $70{ }^{\circ} \mathrm{C}$ e $\mathrm{pH}$ entre 4,5 e $5{ }^{48,124,125} \mathrm{O}$ aquecimento pode favorecer a diminuição da cristalinidade e a mobilidade da água de hidratação, fatores que inibem a ação da celulase. Simulações moleculares têm sido usadas para modelar a estruturação da água adjacente a duas diferentes faces da celulose I $\beta$ monoclínica e microcristalina. ${ }^{126}$ Moléculas de água adjacente foram encontradas na primeira camada de hidratação, devido às ligações de hidrogênio entre as hidroxilas das unidades glicosídicas e à hidratação das superfícies hidrofóbicas resultantes dos átomos de hidrogênio alifáticos (C6) axiais do "topo" das unidades de monômeros de glicose. As camadas altamente estruturadas de água podem representar uma barreira substancial à aproximação da celulase em direção à superfície $(1,0,0)$ na hidrólise catalisada por enzimas, e pode inibir significantemente o escape de produtos solúveis em hidrólise com ácido diluído, contribuindo para as taxas lentas de hidrólise observadas experimentalmente. Já a face $(1,1,0)$ induz muito menos estruturação e pode ser mais facilmente hidrolisada.

A remoção de hemicelulose aumenta o rendimento da hidrólise enzimática de celulose. ${ }^{127-130}$ Ligninas também devem ser removidas porque celulase adsorve sobre elas ${ }^{131,132} \mathrm{e}$ impede o intumescimento das fibras de celulose. ${ }^{133-137}$

Todas as celulases principais do T. reesei têm aminoácidos hidrofóbicos expostos em sua superfície, que podem interagir com a superfície hidrofóbica da lignina. ${ }^{138}$ Este tipo de adsorção não específica de celulases pode causar inativação da enzima durante a hidrólise, reduzindo a eficiência do processo catalítico. ${ }^{132,135,139} \mathrm{Uma}$ forma de minimizar este tipo de adsorção não específica da celulase é a adição de surfactantes ao meio reacional. ${ }^{140}$ Surfactantes não iônicos (como o Tween ou Triton) favorecem a hidrólise, ${ }^{141}$ enquanto que surfactantes carregados desfavorecem a hidrólise.

Como já discutido, a biomassa é um material complexo. Para a hidrólise de hemicelulose há enzimas específicas, como as xilanases ou mananases. Entretanto, não se sabe como a ação destas hemicelulases afeta o desempenho das celulases. ${ }^{142}$ Hemicelulases são produzidas por muitas espécies de bactérias e fungos, assim como por várias plantas. Muitos micro-organismos produzem um padrão múltiplo de hemicelulases para degradar o material vegetal eficientemente. Hoje, preparações de hemicelulases comerciais são obtidas a partir dos fungos Trichoderma ou Aspergillus geneticamente modificados. ${ }^{19}$

Uma parte majoritária dos trabalhos publicados sobre hemicelulases lida com as propriedades e modos de ação, assim como com aplicações das xilanases. Devido à sua natureza complexa, a hidrólise enzimática da xilana é mais complicada do que a maioria dos polissacarídeos vegetais, por causa das ramificações das cadeias. Tipicamente, as ramificações das xilanas são removidas e depois o esqueleto é despolimerizado. Conforme os substituintes são removidos, a xilana pode se tornar menos solúvel e formar agregados que impedem estericamente a continuação da degradação. A remoção simultânea dessas cadeias secundárias e a clivagem do esqueleto polimérico sinergicamente aumentam a taxa de degradação por enzimas endoxilanase. ${ }^{143}$

\section{CONSIDERAÇÕES FINAIS}

A produção de etanol a partir de celulose é um desafio que vem provocando vários pesquisadores em muitos países. ${ }^{144} \mathrm{O}$ etanol é inegavelmente um combustível menos poluidor e, especialmente no caso do Brasil, ${ }^{145}$ a polêmica alimentos versus combustível perde força. Um exemplo disto é a implementação de programas de pesquisa voltados para pesquisa de conversão de biomassa de cana-de-açúcar em etanol. ${ }^{13}$ Apesar da obtenção do etanol a partir de fermentação da glicose ser uma etapa já bem controlada, o grande desafio ainda é a obtenção de glicose a partir de celulose (biomassa) usando métodos "limpos", onde altas temperatura e pressão e solventes orgânicos são desnecessários, e economicamente viáveis.

\section{AGRADECIMENTOS}

À Fundação de Amparo à Pesquisa do Estado de São Paulo e ao Conselho Nacional de Pesquisa e Desenvolvimento pelo apoio financeiro.

\section{REFERÊNCIAS}

1. Goldemberg, J. Em Bioenergia no Estado de São Paulo; Nigro, F. E. B.; Coelho, S. T., eds.; Imprensa Oficial do Estado de São Paulo: São Paulo, 2008, p. 110; World Energy Assessment - WEA 2000; Energy and the challenge of sustainability, United Nations Development Programme, United Nations Development of Economic and Social Affairs and World Energy Council.

2. Marques, F.; Pesquisa FAPESP 2008, 149, 20.

3. Goyal, A.; Ghosh, B.; Eveleigh, D.; Bioresour. Technol. 1991, 36, 37.

4. Wyk, J. P. H. van; Trends Biotechnol. 2001, 19, 172.

5. Galembeck, F.; Anais do Simpósio da Academia Brasileira de Ciências, São Paulo, 1997; Galembeck, F.; Barbosa, C. A. S.; Sousa, R. A.; Quim. Nova 2009, 32, 571.

6. Hahn-Hagerdal, B.; Galbe, M.; Gorwa-Grauslund, M. F.; Liden, G.; Zacchi, G.; Trends Biotechnol. 2006, 24, 549.

7. Goldemberg, J.; Science 2007, 315, 808.

8. Wheals, A. E.; Basso, L. C.; Alves, D. M.; Amorim, H. V.; Trends Biotechnol. 1999, 17, 482.

9. Zanin, G. M.; Santana, C. C.; Bon, E. P. S.; Giordano, R. C. L.; de Moraes, F. F.; Andrietta, S. R.; Carvalho Neto, C. C.; Macedo, I. C.; Fo, D. L.; Ramos, L. P.; Fontana, J. D.; Appl. Biochem. Biotechnol. 2000, 84, 1147.

10. http://www.unica.com.br, acessada em Março 2010.

11. Ereno, D.; Cesar, E.; Pesquisa FASPESP 2007, 133, 28.

12. Stambuk, B. U.; Eleutherio, E. C. A.; Florez-Pardo, L. M.; Souto-Maior, A. M.; Bon, E. P. S.; J. Sci. Ind. Res. 2008, 67, 918.

13. http://bioenfapesp.org, acessada em Março 2010.

14. http://www.agencia.fapesp.br/materia/10838/especiais/pontape-inicial. htm, acessada em Março 2010.

15. http://www.fapesp.br/materia/5064, acessada em Março 2010.

16. Guimarães, M.; Pesquisa FAPESP 2009, 158, 65.

17. http://www.fapesp.br/materia/4816/bioen/workshop-bioen-ppp-etanolon-sugarcane-photosynthesis-18-2-2009-.htm, acessada em Março 2010.

18. http://www.fapesp.br/materia/60/politicas-publicas/politicas-publicas. htm, acessada em Março 2010.

19. Wyman, C. E.; Decker, S. R.; Himmel, M. E.; Brady, J. W.; Skopec, C. E.; Viikari, L. Em Polysaccharides: Strutural Diversity and Functional Versatility; Dumitriu, S., ed.; Dekker: New York, 2005, cap. 43.

20. Lora, J. S.; Glasser, W. G.; J. Polym. Environ. 2002, 10, 39.

21. Kadla, J. K.; Kubo, S.; Venditti, R. A.; Gilbert, R. D.; Compere, A. L.; Griffith, W.; Carbon 2002, 40, 2913

22. Olsson, L.; Jørgensen, H.; Krogh, K. B. R.; Roca, C. Em ref. 19, cap. 42.

23. Barl, B.; Biliaderis, C. G.; Murray, D. M.; MacGregor, A. W.; J. Sci. Food Agric. 1991, 56, 195.

24. Wiselogel, A.; Tyson, J.; Johnsson, D. Em Handbook on Bioethanol: Production and Utilization; Wyman, C. E., ed.; Taylor \& Francis: Washington, 1996, p. 105.

25. Brown, R. M.; Pure Appl. Chem. 1999, 71, 767.

26. Bjerre, A. B.; Olesen, A. B.; Fernqvist, T.; Ploger, A.; Schmidt, A. S.; Biotechnol. Bioeng. 1996, 49, 568.

27. O'Sullivan, A. C.; Cellulose 1997, 4, 173.

28. Mark, H.; Meyer, K. H.; Ber. Dtsch. Chem. Ges 1928, 61, 593.

29. Kroon-Batenburg, L. M. J.; Bouma, B.; Kroon, J.; Macromolecules 1996, 29, 5695

30. Kadla, J. F.; Gilbert, R. D.; Cell. Chem. Technol. 2000, 34, 197. 
31. Heiner, A. P.; Teleman, O.; Pure Appl. Chem. 1996, 68, 2187.

32. Spiridon, I.; Popa, V. I. Em ref. 19, cap. 18.

33. Whitney, S. E.; Gothard, M. G.; Mitchell, J. T.; Gidley, M. J.; Plant Physiol. 1999, 121, 657.

34. Fujino, T.; Sone, Y.; Mitsuishi, Y.; Itoh, T.; Plant Cell. Physiol. 2000, 41, 486.

35. Prade, R. A.; Biotechnol. Genet. Eng. Rev. 1996, 13, 101.

36. Gielkens, M. M.; Visser, J.; de Graaff, L. H.; Curr. Genet. 1997, 31, 22.

37. Eriksson, O.; Goring, D. A. I.; Lindgren, B. O.; Wood Sci. Technol. 1980, 14, 267.

38. Hartley, R. D.; Ford, C. W.; ACS Symp. Ser. 1989, 399, 137.

39. Matsuo, T.; Mizuno, T.; Agric. Biol. Chem. 1974, 38, 465.

40. Biely, P.; Puls, J.; Schneider, H.; FEBS Lett. 1985, 186, 80.

41. Petkowicz, C. L. D.; Reicher, F.; Chanzy, H.; Taravel, F. R.; Vuong, R.; Carbohydr. Polym. 2001, 44, 107.

42. Lynd, L. R.; Wyman, C. E.; Biotechnol. Progr. 1999, 15, 777.

43. Li, X.; Converse, A. O.; Wyman, C. E.; Biotechnol. Appl. Biochem. 2003, 107, 515.

44. Wright, J. D.; Chem. Eng. Prog. 1988, 62; Wright, J. D.; Wyman, C. E.; Grohmann, K.; Biotechnol. Appl. Biochem. 1987, 18, 75; Linder, M.; Mattinen, M.-L.; Kontteli, M.; Lindeberg, G.; Stahlberg, J.; Drakenberg, T.; Reinkainen, T.; Pettersson, G.; Annila, A.; Protein Sci. 1995, 4, 1056; Wyman, C. E.; Annu. Rev. Energy Environ. 1999, 24, 189.

45. Castro, A. M.; Pereira Jr, N.; Quim. Nova 2010, 33, 181.

46. Saloheimo, M.; Nakari-Setala, T.; Tenkanen, M.; Penttilã, M.; Eur. J. Biochem. 1997, 249, 548.

47. Divne, C.; Ståhlberg, J.; Reinikainen, T.; Ruohonen, L.; Petterson, G.; Knowles, J. C. K.; Teeri, T. T.; Jones, T. A.; Science 1994, 265, 524.

48. Tébéka, I. R. M.; Silva, A. G. L.; Petri, D. F. S.; Langmuir 2009, 25, 1582.

49. Henrissat, B.; Biochem. J. 1991, 280, 309

50. Eriksson, T.; Karlsson, J.; Tjerneld, F.; Biotechnol. Appl. Biochem. 2002, 101,41 .

51. Karlsson, J.; Medve, J.; Tjerneld, F.; Biotechnol. Appl. Biochem. 1999, 82, 243.

52. von Sivers, M.; Zacchi, G.; Bioresour. Technol. 1995, 51, 43.

53. Parisi, F.; Adv. Biochem. Eng. Biot. 1989, 38, 53.

54. Jones, J. L.; Semrau, K. T.; Biomass 1984, 5, 109.

55. Lee, Y. Y.; Iyer, P.; Torget, R. W. Em Recent Progress in Bioconversion of Lignocellulosics; Tsao, G. T., ed.; Springer-Verlag: Berlin, 1999, p. 65 e 93.

56. Kadam, K. L.; Wooley, R. J.; Aden, A.; Nguyen, Q. A.; Yancey, M. A.; Ferraro, F. M.; Biotechnol. Progr. 2001, 16, 947.

57. Esteghlalian, A.; Hashimoto, A. G.; Fenske, J. J.; Penner, M. H.; Bioresour. Technol. 1997, 59, 129.

58. Vinzant, T. B.; Ehrman, C. I.; Himmel, M. E.; Biotechnol. Appl. Biochem. 1997, 62, 97.

59. Dadi, A. P.; Varanasi, S.; Schall, C. A.; Biotechnol. Bioeng. 2006, 95, 904.

60. Ghosh, P.; Ghose, T. K. Em Advances in Biochemical Engineering/ Biotechnology; Scheper, T., ed.; Springer: New York, 2003, vol. 85.

61. Sousa, L. C.; Chundawat, S. P. S.; Balan, V.; Dale, B. E.; Curr. Opin. Biotechnol. 2009, 20, 339.

62. Fan, L. T.; Lee, Y. H.; Beardmore, D. R.; Biotechnol. Bioeng. 1981, 23 419.

63. Sun, Y.; Cheng, J. Y.; Bioresour. Technol. 2002, 83, 1; Saddler, J. N.; Ramos, L. P.; Breuil, C. Em Bioconversion of Forest and Agricultural Plant Residues; Saddler, J. N., ed.; CAB International: Wallingford, 1993, p. 73.

64. Öhgren, K.; Bura, R.; Saddler, J.; Zacchi, G.; Bioresour. Technol. 2007, 98, 2503.

65. Chen, H.; Liu, L.; Yang, X.; Li, Z.; Biomass Bioenergy 2005, 28, 411; Playne, M. J.; Biotechnol. Bioeng. 1984, 26, 426; Ewanick, S. M.; Bura R.; Saddler, J. N.; Biotechnol. Bioeng. 2007, 98, 737; Brownell, H. H.;
Saddler, J. N.; Biotechnology and Bioengineering Symposium, Gatlinburg, EUA, 1984, vol. 14, p. 55

66. http://www.mascoma.com/, acessada em Março 2010.

67. Heinze, T.; Koschella, A.; Polimeros 2005, 15, 84.

68. Zhang, Y. -H. P.; Ding, S. -Y.; Mielenz, J. R.; Cui, J. B.; Elander, T. T.; Laser, M.; Himmel, M. E.; McMillan, J. R.; Lynd, L. R.; Biotechnol. Bioeng. 2007, 97, 214.

69. Zhao, Z.; Li, C.; Faming Zhuanli Shenqing Gongkai Shuomingshu CN101289817-A 2008. (CA 149:536105); Nojiri, N.; Jpn. Kokai Tokkyo Koho JP2009159904-A 2009. (CA 151:175883).

70. Swatloski, R. P.; Spear, S. K.; John, D.; Holbrey, J. D.; Rogers, R. D.; J. Am. Chem. Soc. 2002, 124, 4974; Zhao, H.; Jones, C. L.; Baker, G. A.; Xia, S.; Olubajo, O.; Person, V. N.; J. Biotechnol. 2009, 139, 47; Zavrel, M.; Bross, D.; Funke, M.; Büchs, J.; Spiess, A. C.; Bioresour. Technol. 2009, 100, 2580; Mazza, M.; Catana, D.-A.; Vaca-Garcia, C.; Cecutti, C.; Cellulose 2009, 16, 207.

71. Zhu, S.; Wu, Y.; Chen, Q.; Yu, Z.; Wang, C.; Jin, S.; Ding, Y.; Wu, G.; Green Chem. 2006, 8, 325 .

72. El Seoud, O. A.; Koschella, A.; Fidale, L. C.; Dorn, S.; Heinze, T.; Biomacromolecules 2007, 8, 2629.

73. Fidale, L. C.; Possidonio, S.; Seoud, O. A. E.; Macromol. Biosci. 2009, 9,813

74. Ogeda, T. L.; Petri, D. F. S.; resultados não publicados.

75. Turner, M. B.; Spear, S. K.; Huddleston, J. G.; Holbrey, J. D.; Rogers, R. D.; Green Chem. 2003, 5, 443.

76. Kamiya, N.; Matsushita, Y.; Hanaki, M.; Nakashima, K.; Narita, M.; Goto, M.; Takahashi, H.; Biotechnol. Lett. 2008, 30, 1037.

77. Li, C.; Zhao, Z.K.; Adv. Synth. Catal. 2007, 349, 1847.

78. Ljungdahl, L.G.; Eriksson, K.-E. Em Advances in Microbial Ecology; Marshall, K.C., ed.; Plenum Pub. Corp.: New York, 1985, p. 237.

79. Elisashvili, V. I.; Khardziani, T. S.; Tsiklauri, N. D.; Kachlishvili, E. T.; Biochemistry (Mosc.) 1999, 64, 718.

80. Rabinovich, M. L.; Melnik, M. S.; Boloboba, A. V.; Appl. Biochem. Microbiol. 2002, 38, 305 .

81. Hodrova, B.; Kopecny, J.; Kas, J.; Res. Microbiol. 1998, 149, 417.

82. White, B. A.; Cann, I. K. O.; Mackie, R. I.; Morrison, M. Em Rumen Microbes and Digestive Physiology of Ruminants; Onodera, R., ed.; Japan Scientific Societies Press: Tokyo, 1997, p. 69.

83. Liu, J. H.; Selinger, L. B.; Hu, Y. J.; Moloney, M. M.; Cheng, K. J.; Beauchemin, K. A.; Can. J. Microbiol. 1997, 43, 477.

84. Morgavi, D. P.; Sakurada, M.; Mizokami, M.; Tomita, Y.; Onodera, R.; Appl. Environ. Microbiol. 1994, 60, 3718.

85. Li, X. L.; Calza, R. E.; Appl. Environ. Microbiol. 1991, 57, 3331.

86. Raghothama, S.; Eberhardt, R. Y.; Simpson, P.; Wigelsworth, D.; White, P.; Hazlewood, G. P.; Nagy, T.; Gilbert, H. J.; Williamson, M. P.; Nat. Struct. Mol. Biol. 2001, 8, 775 .

87. Gilbert, H. J.; Hazlewood, G. P.; Laurie, J. I.; Orpin, C. G.; Xue, G. P.; Mol. Microbiol. 1992, 6, 2065.

88. Coughlan, M. P.; Ljungdahl, L. G. Em Biochemistry and Genetics of Cellulose Degradation; Aubert, J. P.; Beguin, P.; Millet, J., eds.; Academic Press: New York, 1988, p. 11.

89. Borneman, W. S.; Ljungdahl, L. G.; Hartley, R. D.; Akin, D. E. Em Hemicellulose and Hemicellulases; Coughlan, M. P.; Hazlewood, G. P.; eds.; Portland Press: London, 1983, p. 85.

90. Lynd, L. R.; Weimer, P. J.; van Zyl, H.; Pretorius, I. S.; Microbiol. Mol. Biol. R. 2002, 66, 506.

91. Mendgen, K.; Deising, H.; New Phytol. 1993, 124, 193.

92. Daniel, G.; FEMS Microbiol. Rev. 1994, 13, 199

93. Sakon, J.; Irwin, D.; Wilson, D. B.; Karplus, P. A.; Nat. Struct. Mol. Biol. 1997, 4, 810 .

94. Spiridonov, N. A.; Wilson, D. B.; J. Bacteriol. 1998, 180, 3529.

95. Bothwell, M. K.; Wilson, D. B.; Irwin, D. C.; Walker, L. P.; Enzyme Microb. Technol. 1997, 20, 411. 
96. Bayer, E. A.; Shoham, Y.; Lamed, R. Em Glycomicrobiology; Doyle, R. J., ed.; Kluwer Academic/Plenum Publishers: New York, 2000, p. 387.

97. Bayer, E. A.; Morag, E.; Lamed, R.; Trends Biotechnol. 1994, 12, 378.

98. Doi, R. H.; Tamura, Y.; Chem. Rec. 2001, 1, 24.

99. Bayer, E. A.; Chanzy, H.; Lamed, R.; Shoham, Y.; Curr. Opin. Struct. Biol. 1998, 8, 548.

100. Schwarz, W. H.; Appl. Microbiol. Biot. 2001, 56, 634.

101. Shoham, Y.; Lamed, R.; Bayer, E. A.; Trends Microbiol. 1999, 7, 275.

102. Tamaru, Y.; Liu, C.-C.; Ichi-ishi, A.; Malburg, L.; Doi, R. H. Em Biochemistry and Ecology of Cellulose Degradation; Ohmiya, K. H. K.; Sakka, K.; Kobayashi, Y.; Karita, S.; Kimura, T.; eds.; Uni Publishers Co.: Tokyo, 1999, p. 488.

103. Linder, M.; Teeri, T. T.; J. Biotechnol. 1997, 57, 15.

104. Chauvaux, S.; Matuschek, M.; Beguin, P.; J. Bacteriol. 1999, 181, 2455; Boraston, A. B.; McLean, B. W.; Kormos, J. M.; Alam, M.; Gilkes, N. R.; Haynes, C. A.; Tomme, P.; Kilburn, D. G.; Warren, R. A. Em Recent Advances in Carbohydrate Bioengineering; Gilbert, H. J.; Davies, G. J.; Henrissat, B.; Svensson, B., eds.; The Royal Society of Chemistry: Cambridge, 1999, p. 202; Sieben, A.; Anal. Biochem. 1975, 63, 214.

105. Gilkes, N. R.; Kwan, E.; Kilburn, D. G.; Miller, R. C.; Warren, R. A. J.; J. Biotechnol. 1997, 57, 83 .

106. Hoshino, K.; Yamasaki, H.; Chida, C.; Morohashi, S.; Sasakura, T.; Taniguchi, T. M.; Fujii, M.; J. Chem. Eng. Jpn. 1997, 30, 30.

107. Irwin, D. C.; Spezio, M.; Walker, L. P.; Wilson, D. B.; Biotechnol. Bioeng. 1993, 42, 1002.

108. Sadana, J. C.; Patil, R. V.; Carbohydr. Res. 1985, 140, 111.

109. Katzen, R.; Othmer, D. F.; Ind. Eng. Chem. Res. 1942, 34, 314.

110. Ooshima, H.; Kurakake, M.; Kato, J.; Harano, Y.; Biotechnol. Appl. Bioc. 1991, 31, 253.

111. Saeman, J. F.; Ind. Eng. Chem. Res. 1945, 37, 42.

112. Lyklema, J.; Norde, W.; Prog. Colloid Polym. Sci. 1996, 9, 101.

113. Pancera, S. M.; Gliemann, H.; Schimmel, T.; Petri, D. F. S.; J. Colloid Interface Sci. 2006, 302, 417; Castro, L. B. R.; Silva, F. S.; CarmonaRibeiro, A. M.; Kappl, M.; Petri, D. F. S.; J. Phys. Chem. B 2007, 111, 8520; Pancera, S. M.; Almeida, A. T.; Petri, D. F. S.; Privilégio de Inovação n.0600304-4, Kit para análises clínicas utilizando enzimas imobilizadas, 04 de Abril de 2006 (Depósito).

114. Almeida, A. T.; Salvadori, M. C.; Petri, D. F. S.; Langmuir 2002, 18, 6914.

115. Frenkel-Mullerad, H.; Avnir, D.; J. Am. Chem. Soc. 2005, 127, 8077; Caseli, L.; Oliveira, R. G.; Masui, D. C.; Furriel; R. P. M.; Leone, F. A.; Maggio, B.; Zaniquelli, M. E. D.; Langmuir 2005, 21, 4090.

116. Pancera, S. M.; Gliemann, H.; Schimmel, T.; Petri, D. F. S.; J. Phys. Chem. B 2006, 110, 2674; Pancera, S. M.; Alvarez, E. B.; Politi, M. J.; Gliemann, H.; Schimmel, T.; Petri, D. F. S.; Langmuir 2002, 18, 3517.

117. Naves, A. F.; Carmona-Ribeiro, A. M.; Petri, D. F. S.; Langmuir 2007, 23, 1981; Silva, R. A.; Carmona-Ribeiro, A.-M.; Petri, D. F. S.; Int. J. Biol. Macromol. 2007, 41, 404; Schmidt, T. F.; Caseli, L.; Viitala, T.; Oliveira Jr, O. N.; Biochim. Biophys. Acta 2008, 1778, 2291.

118. Li, C.; Yoshimoto, M.; Fukunaga, K.; Nakao, K.; Bioresour. Technol. 2007, 98, 1366.

119. Mao, X.; Guo, G.; Huang, J.; Du, Z.; Huang, Z.; Ma, L.; Li, P.; Gu, L.; J. Chem. Technol. Biot. 2006, 81,189 .

120. Wu, L.; Yuan, X.; Sheng, J.; J. Membr. Sci. 2005, 250, 167.
121. Vaillant, F.; Millan, A.; Millan, P.; Dornier, M.; Decloux, M.; Reynes, M.; Process Biochem. 2000, 35, 989.

122. Chakrabarti, A. C.; Storey, K. B.; Biotechnol. Appl. Biochem. 1988, 19, 189.

123. Ge, Y.; Burmaa, B.; Zhang, S.; Wang, S.; Zhou, H.; Li, W.; Biotechnol. Tech. 1997, 11, 359.

124. Yuan, X.; Shen, N.; Wei, X.; J. Membr. Sci. 1999, 155, 101.

125. Gole, A.; Vyas, S.; Sainkar, S. R.; Lachke, A.; Sastry, M.; Langmuir 2001, 17, 5964

126. Skopec, C.; Zuccato, P.; Brady, J. W.; Torget, R.; Himmel, M. E.; Carbohydr. Res. 2006, 341, 138.

127. Grohmann, K.; Torget, R.; Himmel, M. E.; Biotechnol. Bioeng. 1985, $15,59$.

128. Grethlein, H. E.; Bio-Technol. 1985, 3, 155.

129. Stone, J. E.; Scallan, A. M.; Adv. Chem. Sci. 1969, 95, 219.

130. Saddler, J. N.; Brownell, H. H.; Clermont, L. P.; Levitin, N.; Biotechnol. Bioeng. 1982, 24, 1389; Brownell, H. H.; Saddler, J. N.; Biotechnol. Bioeng. 1987, 29, 228; Puls, J.; Poutanen, K.; Korner, H. U.; Viikari, L.; Appl. Microbiol. Biot. 1985, 22, 416; Puls, J.; Schuseil, J. Em Chemistry of hemicellulose: Relationship between hemicellulose structure and enzymes required for hydrolysis; Coughlan, M. P.; Hazlewood, G. P., eds.; Portland Press: London, 1993, p. 1.

131. Clark, T. A.; Mackie, K. L.; Dare, P. H.; McDonald, A. G.; J. Wood Chem. Technol. 1989, 9, 135.

132. Kadam, K. L.; Schmidt, S. L.; Appl. Microbiol. Biotechnol. 1997, 48, 709 .

133. Krishna, S. H.; Reddy, T. J.; Chowdary, G. V.; Bioresour. Technol. 2001 , $77,193$.

134. Nilsson, U.; Barron, N.; McHale, L.; McHale, A. P.; Biotechnol. Lett. 1995, 17, 985.

135. Pack, S. P.; Cho, K. M.; Kang, H. S.; Yoo, Y. J.; J. Microbiol. Biotechnol. 1998, 8, 441.

136. Bollok, M.; Reczey, K.; Zacchi, G.; Biotechnol. Appl. Biochem. 2000, $69,84$.

137. Mansfield, S. D.; Mooney, C.; Saddler, J. N.; Biotechnol. Progr. 1999, $15,804$.

138. Vlasenko, E. Y.; Ding, H.; Labavitch, J. M.; Shoemaker, S. P.; Bioresour. Technol. 1997, 59, 109.

139. Saddler, J. N.; Ramos, L. P.; Breuil, C. Em Bioconversion of Forest and Agricultural Plant Residues; Saddler, J. N., ed.; CAB International: Wallingford, 1993, p. 73

140. Donaldson, L. A.; Wong, K. K. Y.; Mackie, K. L.; Wood Sci. Technol. 1988, 22, 103; Cowling, E. B.; Kirk, T. K.; Biotechnol. Bioeng. 1976, 95; Converse, A. O.; Ooshima, H.; Burns, D. S.; Biotechnol. Appl. Biochem. 1990, 24, 67.

141. Kurakake, M.; Shirasawa, T.; Ooshima, H.; Converse, A. O.; Kato, J.; Biotechnol. Appl. Biochem. 1995, 50, 231.

142. Kim, K. H.; Tucker, M. P.; Nguyen, Q. A.; Biotechnol. Progr. 2002, 18, 489.

143. Gielkens, M. M.; Visser, J.; de Graaff, L. H.; Curr. Genet. 1997, 31, 22.

144. Himmel, M. E; Ding, S.; Johnson, D. K.; Adney, W. S.; Nimlos, M. R.; Brady, J. W.; Foust, T. D.; Science 2007, 315, 804

145. Nass, L. L.; Pereira, P. A. A.; Ellis, D.; Crop Sci. 2007, 47, 2228. 